\title{
C-H-O Stable Isotope, Elements and Fluid Geochemistry of Uraniferous Leucogranites in Gaudeanmus Area, Southern Central Zone, Damara Orogen, Namibia
}

\author{
Jinyong Chen ${ }^{1,2}{ }^{*}$, Honghai Fan ${ }^{1,2}$, Shengyun Wang1,2, Dazhao Gu ${ }^{1,2}$ \\ ${ }^{1}$ Beijing Research Institute of Uranium Geology, Beijing, China \\ ${ }^{2}$ Key Laboratory of Uranium Resource Exploration and Evaluation Technology, CNNC, Beijing, China \\ Email: *jinyong20060309@163.com
}

How to cite this paper: Chen, J.Y., Fan, H.H., Wang, S.Y. and Gu, D.Z. (2017) C-HO Stable Isotope, Elements and Fluid Geochemistry of Uraniferous Leucogranites in Gaudeanmus Area, Southern Central Zone, Damara Orogen, Namibia. Journal of Geoscience and Environment Protection, 5, 118.

https://doi.org/10.4236/gep.2017.52001

Received: September 16, 2016 Accepted: February 7, 2017

Published: February 14, 2017

\begin{abstract}
This paper focuses on the effect of the later hydrotherm on uraniferous leucogranites and the stages of uranium mineralization. Here, we review $\mathrm{C}-\mathrm{H}-\mathrm{O}$ stable isotope, elements and fluid geochemistry of uraniferous leucogranites in Gaudeanmus, Namibia. The results show that there is significant increasing amount of rare earth element from non-mineralized to uraniferous leucogranites, indicating the synchronization of REE enrichment and uranium mineralization. Uranium enrichment may have close relations with $\mathrm{Pb}, \mathrm{Th}, \mathrm{Co}, \mathrm{Ni}$, $\mathrm{REE}$ in this region, so REE and $\mathrm{U}$ evidently exist homology. There are at least two stages of uranium mineralization by later hydrothermal alteration: firstly, due to magnatic residual high temperature and low salinity fluid, the temperature of main metallogenetic epoch ranges from $470^{\circ} \mathrm{C}$ to $530^{\circ} \mathrm{C}$, salinity ranges from $3.55 \%$ to $9.60 \% \mathrm{NaCleq}$, and $\mathrm{C}, \mathrm{H}, \mathrm{O}$ stable isotope is $-23 \%$ $-13.6 \%$ o, $-53.3 \%$ - $-46.4 \%$, $7.71 \%$ - $8.81 \%$, respectively. Secondly, due to superimposed hydrothermal fluid, the temperature, salinity, and $\mathrm{C}, \mathrm{H}, \mathrm{O}$ stable isotope is $150^{\circ} \mathrm{C}-220^{\circ} \mathrm{C}, 4.65 \%$ - $19.05 \%$ NaCleq, $-20.3 \%$ o - $-3.7 \%$, $-64.7 \%$ - $-53.6 \%$, $1.49 \%$ - $1.99 \%$, respectively. The fluid for reformation is derived from postmagmatic fluid, mixed with a number of meteoric water.
\end{abstract}

\section{Keywords}

Geochemistry, C-H-O Stable Isotope, Uranium Mineralization, Leucogranites, Gaudeanmus, Damara Belt

\section{Introduction}

Namibia is located in southwest Africa and very rich in mineral resources. At 
present, there are mainly four types of uranium deposit: intrusive, Surficial and sandstone-hosted. Rössing uranium deposit is the famous leucogranite-type uranium deposits [1]. With the geological work progression, leucogranite-type uranium deposits were discovered in the surrounding areas, including Valencia, Rössing South, Ida Dome, Goanikontes, Gaudeanmus [1]-[11]. The geochronology of monazite $\mathrm{U}-\mathrm{Pb}$ has shown that the $\mathrm{U}-\mathrm{Pb}$ age of leucogranite is about $509 \pm 1 \mathrm{Ma}$, consistent with the age of native uraninite (508 $\pm 2 \mathrm{Ma}$ ) [12] [13]. However, there are disagreements on the mechanism of leucogranite-type uranium deposit. Nex et al. concluded that leucogranite-type uranium deposits were merely related to the magmatic differentiation, didn't experience hydrothermal alteration [13]; Herd found later fluids in the leucogranites, but only related to the formation of secondary uranium uranophane [14]; while Chen et al. found that the pitchblende which was in the uraniferous leucogranites, indicated that leucogranite-type uranium deposits formed by the original magmatic crystallization differentiation and later superimposed hydrothermal alteration [10] [11]. So the opinion may relate to the later hydrothermal alteration, which has not yet reached agreement.

REE, fluid inclusion and $\mathrm{C}-\mathrm{H}-\mathrm{O}$ stable isotope is an important geochemical tracer, a powerful tool for source and the forming mechanism of mineralization [15] [16] [17]. This paper presented the C-H-O stable isotope, elements and fluid geochemistry of the uraniferous leucogranites, discussed which specific trace elements have close relation with uranium mineralization and whether postmineralized hydrotherm has superimposed transformation to the uraniferous leucogranites, and determined the stages of uranium mineralization as well. An essential evidence for metallogenic mechanism was proposed and new geochemical information to research on the metallogenic model and prognosis was provided.

\section{Geological Setting}

The Damara Orogen is a part of the Late Precambrian (Neoproterozoic) and Early Paleozoic (650 - $460 \mathrm{Ma}$ ) system of the Pan-African mobile belt, which transverses the African continent. In Namibia, the Damara Orogen has been divided into a north-south trending coastal branch and a northeast trending inland branch which has been interpreted as a result of the collision between the Congo, Kalahari and Rio de la Plata cratons [18]. The inland branch has been divided into Northern Platform, Northern Zone, northern Certral Zone, southern Certral Zone, Okahandja Lineament Zone, Southern Zone, Southern Margin Zone and Southern Foreland by the lithostratigraphical, structural and metamorphic criteria [19] [20]. The boundaries between the zones are formed by major faults or linear structures with an aeromagnetic expression [21]. Uranium-bearing leucogranites in Namibia occur within the Central Zone of the Damara Orogen [22]. The Gaudeanmus locates in the southern Certral Zone (Figure 1). The distinguishing characteristics of the southern Central Zone are a number of granitoid intrusions and low-pressure high temperature metamor- 


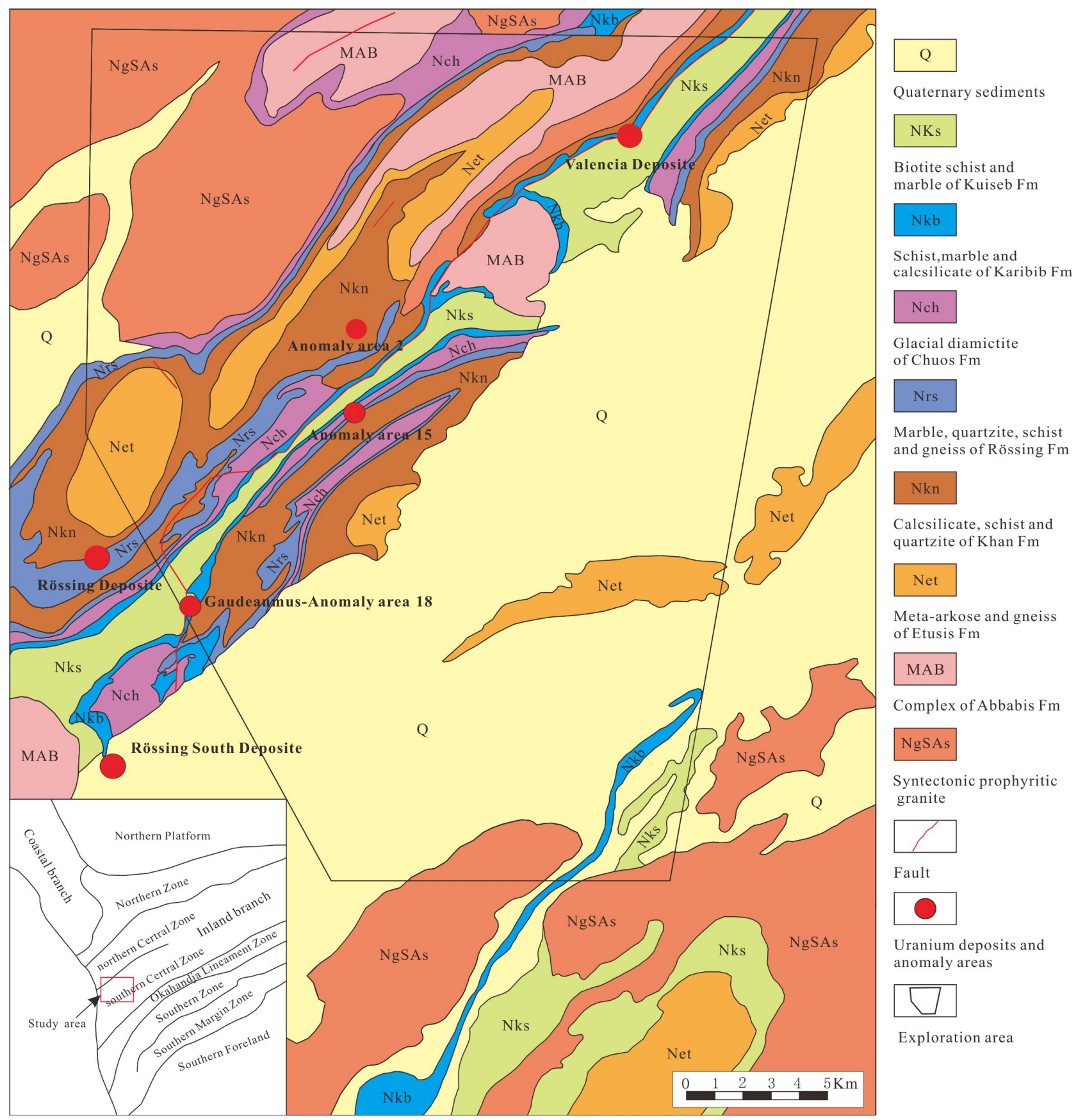

Figure 1. Geological diagram of Gaudeanmus Area, Namibia; showing the location of significant uranium anomalies.

phism at upper-amphibolite to granulite facies [23].

The strata in the Gaudeanmus have been divided into Abbabis Complex, Etusis Formation, Khan Formation, Rössing Formation, Chuos Formation, Karibib Formation, Kuiseb Formation from bottom to top. Abbabis complex is largely composed of augen gneiss and quartzofeldspathic gneiss with a small amount of argillaceous schists, quartzites, marbles, amphibolites. Geochronological studies of the gneisses have resulted in various ages, including $2093 \pm 51 \mathrm{Ma}$ and $1038 \pm$ $58 \mathrm{Ma}$ (U-Pb SHRIMP) [24]. The Etusis formation lies unconformably on the Abbabis metamorphic complex, occurs as cores to several of the prominent 
domes or anticlines in the Gaudeanmus. It is mainly composed of metamorphic conglomerates, quartzites, arkoses, schists, gneisses, etc. In Damara Orogen, Rift-related acid volcanics close to the base of the Damara sequence have been dated at $746 \pm 2$ Ma by Hoffman et al. (1996) [25]. The Khan Formation is distinguished by the grayish-green rocks and numerous granitoid intrusions, and consists of pyroxene-garnet gneisses, schists, amphibolites. It is overlain unconformably by the Rössing Formation, which is dominated by the upper and lower sets of marble, cordierite gneisses and calcsilicates. The uranium-bearing leucogranites intrude mostly into this formation. Chuos Formation which is overlain by a major thickness of glacial diamictite containing a small quantity of calcsilicates and quartzites, and so on. These glacial deposits are interpreted as a result of the worldwide Sturtian glacial event by Hoffman, so Chuos Formation has been dated at $710 \mathrm{Ma}$ [26]. Karibib is composed of thick-bedded marbles, calcsilicates, schists and gneisses, which the thick-bedded marbles developed strong joints. They are overlain by the pelitic schists, gneisses, migmatites, calcsilicates and quartzites of the Kuiseb Foramtion.

\section{Petrology}

In Gaudeanmus, leucogranites are common as sheeted, net-veined, and stratiform-like dykes, and vary in width from $10 \mathrm{~cm}$ to more than $200 \mathrm{~m}$ across. The uraniferous leucogranites intruded into the marble of Rössing and Karibib Formations, gneiss of Khan and Kuiseb Formations. Based on detailed field observations and comparative analysis of cores, we consider that the formation of the rich ores was significantly affected by the hydrothermal alterations, which included albitization (Figure 2(a)), silicification, muscovitization, illitization, kaolinization, sericitization, chloritization (Figure 2(b)), pyritization and limonitization.

The leucogranites are texturally variable: ranging from graphic, and medium-, or coarse-grained granitic to pegmatitic. They are distinguished by the smoke gray, or black quartz. The leucogranites have a simple mineralogy comprising quartz, plagioclase and $\mathrm{K}$-feldspar with minor biotite and muscovite, and develop myrmekite and metasomatic edulcoration border texture (Figure 2(c)). Accessory minerals include zircon, apatite, monazite, epidote, rutile, sphene, pyrite (Figure 2(d)), galena, ilmenite, hematite and various uranium minerals. In majority of leucogranite samples, K-feldspar content is higher or slightly higher than that of plagioclase, therefore, the leucogranites are mostly Syenogranite and adamellite, a small number of alkali-feldspar granite, granodiorite and tonalite.

According to rock-mineral identification and electron microprobe analysis, In Gaudeanmus, the uranium of leucogranite-type uranium deposit mainly exists as independent uranium minerals, and partially exists in thorium minerals as isomorphic form. The uranium minerals are mainly uranium oxides, U-Tioxides and uranium silicates, in which uranium oxides including uraninite, pitchblende (Figure 2(e), Figure 2(f)) and thor-uraninite. Generally, the uraninite varies from a few micrometres to $5 \mathrm{~mm}$ in size (Figure 2(d)), and often occurs 

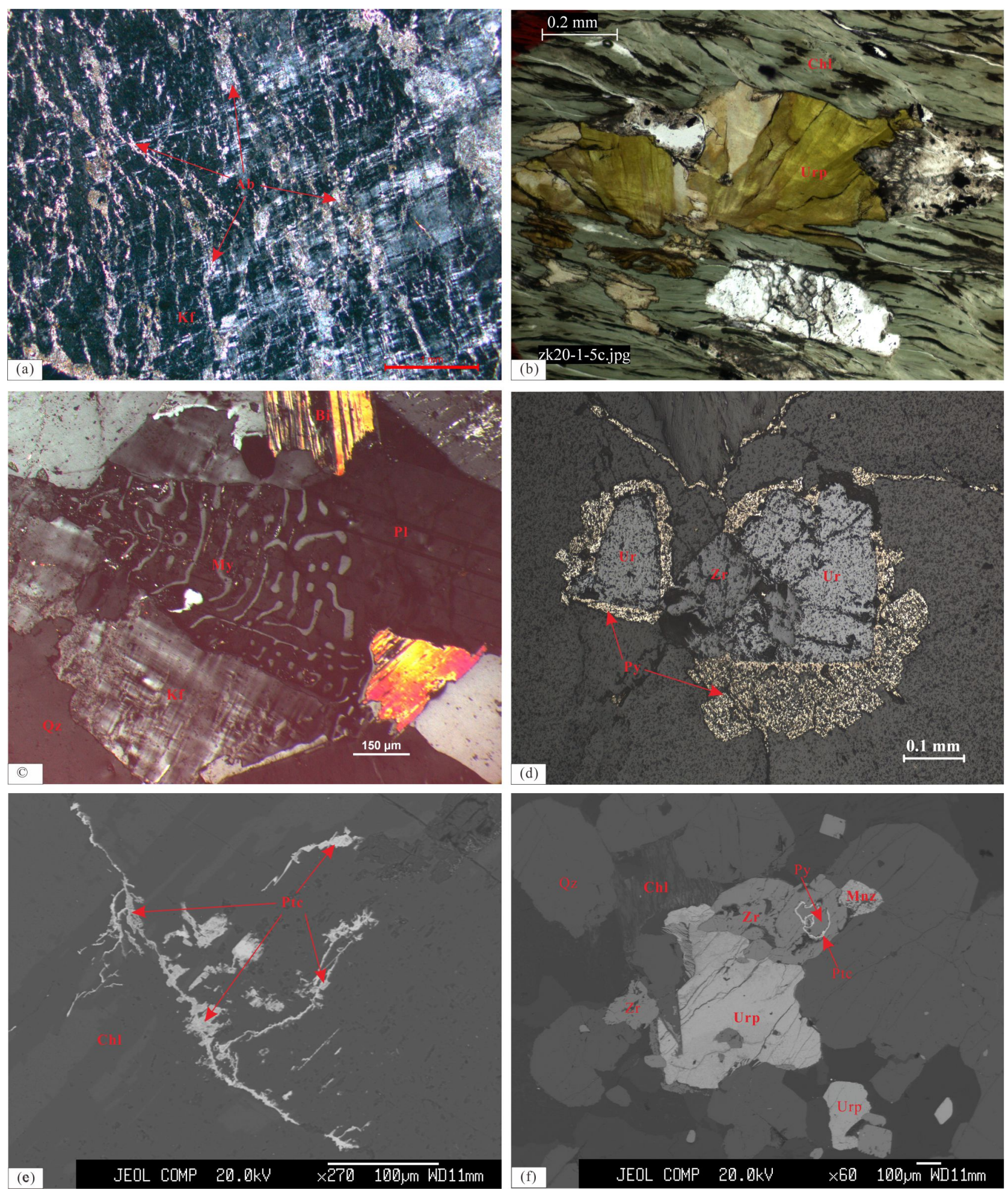

Figure 2. Petrologic and uranium mineral characteristics of leucogranites in Gaudeanmus, Namibia. (a) Feldspar(Kf) occurred albitization(Ab); (b) Biotite(Bi) occurred chloritization(Chl), with uranophane(Urp); (c) Myrmekite (My) grew in the leucogranite; (d) Uraninite(Ur) was surrounded with pyrite(Py), and coexisted with zircon(Zr); (e) Pitchblende(Ptc) filled in the fractures of chlorite (Chl); (f) Pyrite(Py) was surrounded with pitchblende(Ptc), and accompanied with uranophane(Urp), zircon(Zr), monazite(Mnz).

within plagioclase, $\mathrm{K}$-feldspar and biotite. There are many radioactive halos in 
the contact sites of the uraninite, biotite or feldspar. U-Ti-oxides are a complex minerals, including brannerite, betafite, and uranpyrochlore. The uranium silicates contain coffinite, uranophane (Figure 2(b), Figure 2(f)), and uranothorite.

\section{Sample Collection and Analysis}

The leucogranites have been divided into six different types based on field characteristics of petrology, mineralogy and radioactivity [13]. Only the leucogranites which contains smoke gray quartz is the uranium ore. With respect to the purpose of this study, a total of 13 representative samples were collected from the drilling in Gaudeanmus, including non-mineralized leucogranites (ZK11-1120, ZK0-11-9, ZK20-1-3), weak-mineralized leucogranites (ZK0-11-8, ZK0-1110, ZK80-9-2), and uraniferous leucogranites (ZK76-13-5, ZK76-13-6, ZK76-138, ZK76-13-19, ZK80-9-4, LS-1, ZK15-2-7). The detailed sample locations are anomaly area 18 (Figure 1).

The concentrations of trace elements and REE in the samples were measured at the Analytical Laboratory Beijing Research Institute of Uranium Geology, using HR-ICP-MS (Element I) which manufactured by Finnigan-MAT in German, following the methods of the DZ/T0223-2001. The temperature and relative humidity of the laboratory is $20^{\circ} \mathrm{C}$ and $30 \%$, respectively. The contents of trace elements and REE are greater than $10 \mathrm{ppm}$, the relative error is less than $5 \%$, while the contents are less than $10 \mathrm{ppm}$, the relative error is less than $10 \%$. Detailed analytical procedures for trace elements and REE are described by Qu et al. [27].

Doubly polished sections were prepared for fluid inclusion optical examination and microthermometric analysis. Heating and cooling experiments were carried out using a Linkam THMS 600 programmable heating-freezing stage at the Key laboratory of Uranium Resource Exploration and Evaluation Technology, CNNC. The heating rate near ice point and homogenization temperature was $0.1^{\circ} \mathrm{C}$ to $0.2^{\circ} \mathrm{C} / \mathrm{min}$. The reproducibility of measurements was \pm 0.2 below $+30^{\circ} \mathrm{C}$ and \pm 2 above $100^{\circ} \mathrm{C}$, where the chips were centered in the specimen holder.

\section{Elements Geochemistry}

\subsection{Characteristics of Trace Elements}

The measured trace elements concentrations of leucogranites are listed in Table 1 , the uranium contents of non-mineralized, weak-mineralized, uraniferous leucogranites are 13.9 - 87.8 ppm, 187 - 464 ppm, 1201 - 21,053 ppm, respectively. $\mathrm{Rb} / \mathrm{Sr}$ ratios range from 1.07 to $7.53,4.29$ on average, which are significantly higher than that in the crust of eastern China (0.31) and the average of global upper crust (0.32) [28] [29]. This result indicates the leucogranites in Gaudeanmus have high maturity crustal characteristics. $\mathrm{Nb} / \mathrm{Ta}$ ratios are between 8.22 and 35.82, mean 15.18; $\mathrm{Zr} / \mathrm{Hf}$ ratios range 27.76 - 33.72, with an average of 30.84 (except for the sample ZK76-13-8), that are consistent with the geochemical characteristics of crust-derived type granite. Th/U ratios are between 0.07 and 1.22, mean 0.47 (the sample ZK20-1-3 may be rich in thorium 
Table 1. Trace element compositions of the leucogranites in Gaudeanmus, Namibia (ppm).

\begin{tabular}{|c|c|c|c|c|c|c|c|c|c|c|c|c|c|}
\hline \multirow{3}{*}{$\begin{array}{l}\text { Lithology } \\
\text { Sample } \\
\text { No. }\end{array}$} & \multicolumn{3}{|c|}{$\begin{array}{l}\text { Non-mineralized } \\
\text { leucogranites }\end{array}$} & \multicolumn{3}{|c|}{$\begin{array}{l}\text { Weak-mineralized } \\
\text { leucogranites }\end{array}$} & \multicolumn{7}{|c|}{ Uraniferous leucogranites } \\
\hline & ZK11-11 & ZK0-11 & ZK20-1 & ZK0-11 & ZK0-11 & ZK80-9 & ZK76-13 & ZK76-13 & ZK76-13 & ZK76-13 & ZK80-9 & IS-1 & ZK15-2 \\
\hline & -20 & -9 & -3 & -8 & -10 & -2 & -5 & -6 & -8 & -19 & -4 & LS-1 & -7 \\
\hline $\mathrm{Sc}$ & 4.74 & 4.31 & 1.54 & 5.42 & 3.92 & 17.90 & 3.44 & 5.76 & 14.10 & 8.97 & 19.60 & 13.00 & 20.70 \\
\hline $\mathrm{Cr}$ & 10.30 & 4.65 & 2.14 & 2.69 & 2.52 & 10.20 & 4.47 & 5.34 & 5.25 & 4.38 & 18.30 & 21.20 & 31.70 \\
\hline Co & 1.23 & 0.96 & 1.31 & 1.26 & 0.97 & 5.36 & 0.56 & 1.16 & 6.77 & 1.51 & 6.56 & 2.74 & 4.63 \\
\hline $\mathrm{Ni}$ & 1.01 & 0.50 & 1.96 & 1.00 & 0.60 & 3.79 & 0.90 & 1.19 & 4.99 & 2.22 & 8.04 & 1.58 & 4.38 \\
\hline $\mathrm{Cu}$ & 1.35 & 1.23 & 2.47 & 1.35 & 0.79 & 11.00 & 2.16 & 6.52 & 78.40 & 15.90 & 13.10 & 12.10 & 5.49 \\
\hline $\mathrm{Zn}$ & 21.50 & 13.50 & 7.41 & 15.60 & 14.00 & 79.60 & 8.59 & 12.20 & 45.50 & 10.10 & 49.20 & 20.70 & 97.00 \\
\hline $\mathrm{Rb}$ & 296.00 & 335.00 & 141.00 & 288.00 & 296.00 & 408.00 & 496.00 & 398.00 & 155.00 & 421.00 & 339.00 & 157.00 & 211.00 \\
\hline $\mathrm{Sr}$ & 59.30 & 44.50 & 122.00 & 39.80 & 47.20 & 381.00 & 102.00 & 130.00 & 60.20 & 73.50 & 148.00 & 32.50 & 50.80 \\
\hline Y & 22.30 & 14.40 & 17.40 & 30.50 & 31.20 & 140.00 & 84.20 & 65.90 & 974.00 & 215.00 & 892.00 & 371.00 & 120.00 \\
\hline $\mathrm{Nb}$ & 30.00 & 20.10 & 12.70 & 20.80 & 17.50 & 91.50 & 11.10 & 20.20 & 7.98 & 39.10 & 96.00 & 72.70 & 39.90 \\
\hline Mo & 0.53 & 1.87 & 0.32 & 6.56 & 1.35 & 173.00 & 4.51 & 2.45 & 4.33 & 13.80 & 442.00 & 294.00 & 740.00 \\
\hline $\mathrm{Sb}$ & 0.04 & 0.05 & 0.06 & 0.06 & 0.04 & 0.26 & 0.55 & 0.26 & 0.04 & 0.34 & 0.20 & 0.16 & 0.05 \\
\hline Cs & 3.25 & 6.02 & 1.09 & 5.21 & 5.34 & 8.97 & 9.67 & 4.84 & 3.27 & 8.64 & 12.10 & 2.28 & 3.20 \\
\hline $\mathrm{Ba}$ & 119.00 & 139.00 & 76.60 & 115.00 & 122.00 & 159.00 & 471.00 & 310.00 & 128.00 & 324.00 & 171.00 & 118.00 & 321.00 \\
\hline $\mathrm{Ta}$ & 2.98 & 2.14 & 1.05 & 1.42 & 1.68 & 4.70 & 1.35 & 1.48 & 0.28 & 3.98 & 2.68 & 6.08 & 2.96 \\
\hline $\mathrm{W}$ & 2.12 & 1.02 & 1.22 & 1.24 & 1.04 & 3.07 & 2.10 & 1.52 & 4.74 & 9.88 & 4.12 & 7.11 & 7.82 \\
\hline $\mathrm{Pb}$ & 36.60 & 34.60 & 29.70 & 41.80 & 41.40 & 58.40 & 132.00 & 115.00 & 651.00 & 189.00 & 1405.00 & 648.00 & 406.00 \\
\hline Th & 107.00 & 76.50 & 831.00 & 183.00 & 207.00 & 357.00 & 132.00 & 90.80 & 1693.00 & 242.00 & 2805.00 & 709.00 & 382.00 \\
\hline U & 87.80 & 65.00 & 13.90 & 291.00 & 187.00 & 464.00 & 1182.00 & 1201.00 & 10034.00 & 2551.00 & 21053.00 & 9581.00 & 4525.00 \\
\hline $\mathrm{Zr}$ & 87.50 & 37.20 & 291.00 & 276.00 & 170.00 & 258.00 & 640.00 & 761.00 & 615.00 & 2183.00 & 2860.00 & 769.00 & 381.00 \\
\hline $\mathrm{Hf}$ & 3.03 & 1.34 & 9.69 & 9.13 & 5.81 & 8.60 & 19.60 & 23.00 & 3.41 & 67.60 & 89.40 & 25.50 & 11.30 \\
\hline $\mathrm{Nb} / \mathrm{Ta}$ & 10.07 & 9.39 & 12.10 & 14.65 & 10.42 & 19.47 & 8.22 & 13.65 & 28.30 & 9.82 & 35.82 & 11.96 & 13.48 \\
\hline $\mathrm{Zr} / \mathrm{Hf}$ & 28.88 & 27.76 & 30.03 & 30.23 & 29.26 & 30.00 & 32.65 & 33.09 & 180.35 & 32.29 & 31.99 & 30.16 & 33.72 \\
\hline $\mathrm{Th} / \mathrm{U}$ & 1.22 & 1.18 & 59.78 & 0.63 & 1.11 & 0.77 & 0.11 & 0.08 & 0.17 & 0.09 & 0.13 & 0.07 & 0.08 \\
\hline $\mathrm{Rb} / \mathrm{Sr}$ & 4.99 & 7.53 & 1.16 & 7.24 & 6.27 & 1.07 & 4.86 & 3.06 & 2.57 & 5.73 & 2.29 & 4.83 & 4.15 \\
\hline $\mathrm{Ba} / \mathrm{Rb}$ & 0.40 & 0.41 & 0.54 & 0.40 & 0.41 & 0.39 & 0.95 & 0.78 & 0.83 & 0.77 & 0.50 & 0.75 & 1.52 \\
\hline
\end{tabular}

minerals and is excluded), showing the features of magmatogenic granite. And in the non-mineralized and weak-mineralized leucogranites, $\mathrm{Ba} / \mathrm{Rb}$ ratios range from 0.39 to 0.54 , with an average of 0.43 , while the $\mathrm{Ba} / \mathrm{Rb}$ ratios of uraniferous leucogranites are between 0.5 and 1.52 , with an average of 0.87 , consequently it can be used as the indicator to differentiate between the mineralized and nonmineralized leucogranites.

In the primitive mantle-normalized spider diagram of trace elements (Figure 3), all the leucogranites show enrichment in large ion lithophile elements (LILE), especially $\mathrm{Rb}, \mathrm{Th}, \mathrm{U}, \mathrm{Pb}$, and relative depletion in high field strength elements such as $\mathrm{Ti}, \mathrm{P}$. The significant negative anomalies of Sr may be associated with magmatic differentiation or low calcium content in magma, indicating the 

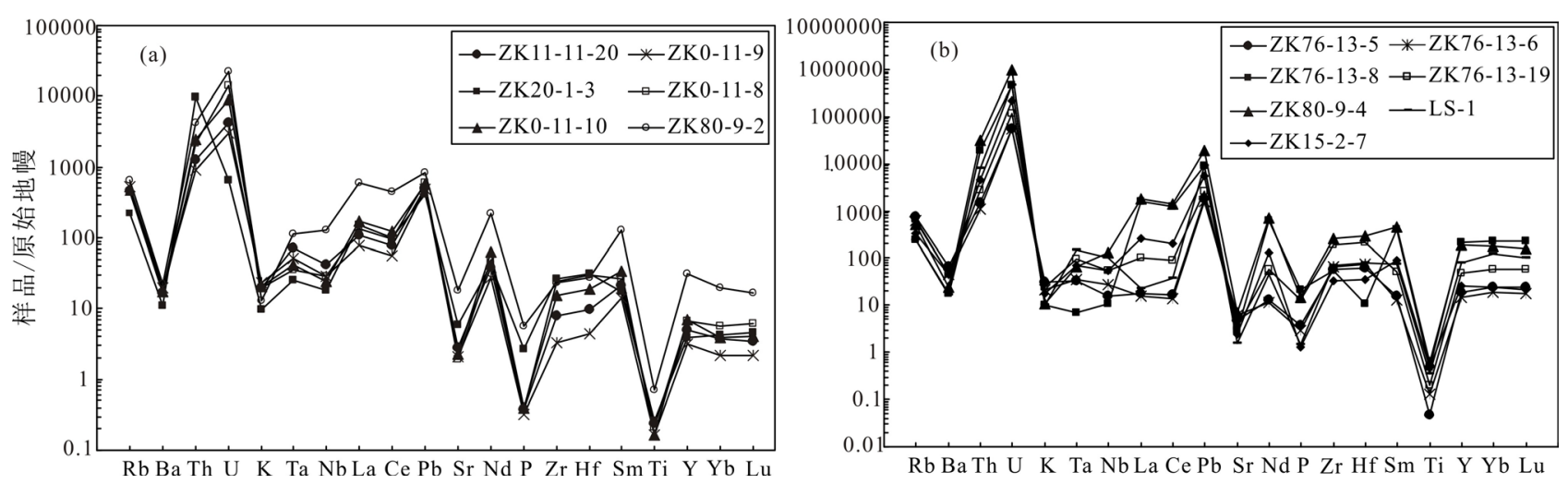

Figure 3. The primitive mantle-normalized spider diagram of trace element in Gaudeanmus, Namibia (data of primitive mantle are from [30]). (a) the diagram of non-mineralized and weak-mineralized leucogranites; (b) the diagram of uraniferous leucogranites.

evolution of partial melting or crystal fractionation of magma might involve the fractionation of a few of plagioclases. The strong negative $\mathrm{Ba}$ anomalies are the characteristics of anorgenic granite, and Ta enrichment also reflects the presence of strong magmatic crystallization differentiation. The depletion of Ti probably results from the fractionation of $\mathrm{Fe}-\mathrm{Ti}$ oxides, indicating that the leucogranites have obviously experienced a high degree of crystallization differentiation.

\subsection{Characteristics of REE}

As listed in Table 2, total rare earth elements (REE) contents of the non-mineralized, weak-mineralized, uraniferous leucogranites are $222.02-377.26 \mathrm{ppm}$ (average $302.59 \mathrm{ppm}$ ), 385.06 - $763.00 \mathrm{ppm}$ (average $878.07 \mathrm{ppm}$ ), 109.19 $5994.28 \mathrm{ppm}$ (average $1925.79 \mathrm{ppm}$ ), respectively. The results show there is an obvious growth trend from non-mineralized to uraniferous leucogranites, which might be related with uranium minerals enriched in REE. There are two types of chondrite-normalized REE patterns of the leucogranites (Figure 4): one is the rightinclining type with obvious Eu negative abnormity and enrichment of LREE (Figure 4(a)); the other is leftinclining type with obvious Eu negative abnormity and enrichment of HREE (Figure 4(b)). The strong Eu depletion $(\delta \mathrm{Eu}=0.03$ 0.47 , average 0.22 ), indicating that the magma experienced strong crystallization differentiation.

The samples of rightinclining type include all non-mineralized, weak-mineralized and some uraniferous leucogranites (ZK76-13-8, ZK80-9-4 and ZK15-2-7), LREE/HREE $=6.63-25.11$, mean 13.60, which gradually decreases from non-mineralized to uraniferous leucogranites. $\delta \mathrm{Eu}=0.03-0.39$, mean 0.18 , reflecting the magma of leucogranites is originated from the partial melting of superficial part of the crust. These samples are relatively enriched in LREE with significant fractionations of HREE and LREE $\left((\mathrm{La} / \mathrm{Yb})_{\mathrm{N}}=6.95-43.79\right.$, mean $25.15)$, and possess weak $\mathrm{Ce}$ anomalies $(\delta \mathrm{Ce}=0.91-1.01$, mean 0.96). $(\mathrm{La} / \mathrm{Sm})_{\mathrm{N}}=2.88-8.49$, mean 4.90 , and $(\mathrm{Gd} / \mathrm{Yb})_{\mathrm{N}}=1.17-4.96$, mean 2.87 respectively, showing an obvious HREE and LREE internal fractionation. These REE patterns indicate that the uranium mineralization mainly resulted from 
Table 2. REE concentrations of the leucogranites in Gaudeanmus, Namibia (ppm).

\begin{tabular}{|c|c|c|c|c|c|c|c|c|c|c|c|c|c|}
\hline Lithology & $\begin{array}{r}\text { Non } \\
\text { let }\end{array}$ & $\begin{array}{l}\text { mineraliz } \\
\text { cogranites }\end{array}$ & & $\begin{array}{r}\text { Wea } \\
\text { le }\end{array}$ & $\begin{array}{l}\text { k-minera } \\
\text { ucogranit }\end{array}$ & $\begin{array}{l}\text { lized } \\
\text { es }\end{array}$ & & & Uranifer & ous leucogr & anites & & \\
\hline \multirow{2}{*}{ Sample No. } & ZK11-11 & ZK0-11 & ZK20-1 & ZK0-11 & ZK0-11 & ZK80-9 & ZK76-13 & ZK76-13 & ZK76-13 & ZK76-13 & ZK80-9 & \multirow{2}{*}{ LS-1 } & ZK15-2 \\
\hline & -20 & -9 & -3 & -8 & -10 & -2 & -5 & -6 & -8 & -19 & -4 & & -7 \\
\hline $\mathrm{La}$ & 73.50 & 53.50 & 103.00 & 90.60 & 116.00 & 405.00 & 12.00 & 10.90 & 1115.00 & 72.20 & 1277.00 & 15.90 & 180.00 \\
\hline $\mathrm{Ce}$ & 139.00 & 101.00 & 176.00 & 170.00 & 216.00 & 796.00 & 29.60 & 25.50 & 2244.00 & 161.00 & 2558.00 & 68.20 & 353.00 \\
\hline $\operatorname{Pr}$ & 15.20 & 11.10 & 18.40 & 20.10 & 25.40 & 85.80 & 3.93 & 3.48 & 243.00 & 20.00 & 279.00 & 11.20 & 48.40 \\
\hline $\mathrm{Nd}$ & 51.50 & 37.10 & 56.90 & 65.80 & 84.50 & 294.00 & 17.30 & 15.20 & 831.00 & 78.90 & 962.00 & 61.20 & 177.00 \\
\hline $\mathrm{Sm}$ & 9.60 & 6.39 & 7.83 & 11.80 & 15.20 & 57.20 & 6.83 & 5.82 & 182.00 & 23.50 & 210.00 & 32.50 & 40.30 \\
\hline $\mathrm{Eu}$ & 0.81 & 0.73 & 0.68 & 0.70 & 0.85 & 1.62 & 1.16 & 0.86 & 2.86 & 1.83 & 2.18 & 1.66 & 1.12 \\
\hline Gd & 7.10 & 4.66 & 5.42 & 9.06 & 11.40 & 46.00 & 8.48 & 7.22 & 163.00 & 26.80 & 187.00 & 38.90 & 32.70 \\
\hline $\mathrm{Tb}$ & 1.11 & 0.75 & 0.71 & 1.49 & 1.71 & 7.73 & 2.49 & 2.03 & 32.90 & 6.84 & 37.50 & 13.30 & 6.76 \\
\hline Dy & 5.28 & 3.47 & 3.35 & 7.38 & 8.42 & 36.80 & 17.90 & 14.30 & 196.00 & 46.00 & 214.00 & 101.00 & 34.60 \\
\hline Ho & 0.82 & 0.54 & 0.57 & 1.21 & 1.21 & 6.16 & 3.76 & 2.95 & 39.40 & 9.34 & 40.80 & 21.50 & 5.35 \\
\hline Er & 2.15 & 1.37 & 1.71 & 3.23 & 2.92 & 14.00 & 11.50 & 8.92 & 114.00 & 27.60 & 109.00 & 65.30 & 14.00 \\
\hline $\mathrm{Tm}$ & 0.33 & 0.19 & 0.28 & 0.48 & 0.36 & 1.90 & 1.97 & 1.52 & 19.50 & 4.70 & 16.70 & 11.00 & 2.12 \\
\hline $\mathrm{Yb}$ & 1.85 & 1.05 & 2.07 & 2.76 & 1.90 & 9.54 & 12.20 & 9.13 & 115.00 & 28.90 & 89.20 & 61.20 & 12.20 \\
\hline $\mathrm{Lu}$ & 0.25 & 0.16 & 0.34 & 0.46 & 0.30 & 1.25 & 1.80 & 1.36 & 17.00 & 4.37 & 11.90 & 7.46 & 1.60 \\
\hline $\mathrm{Y}$ & 22.30 & 14.40 & 17.40 & 30.50 & 31.20 & 140.00 & 84.20 & 65.90 & 974.00 & 215.00 & 892.00 & 371.00 & 120.00 \\
\hline$\Sigma$ REE & 308.50 & 222.02 & 377.26 & 385.06 & 486.16 & 1763.00 & 130.92 & 109.19 & 5314.66 & 511.98 & 5994.28 & 510.32 & 909.15 \\
\hline LREE & 289.61 & 209.82 & 362.81 & 359.00 & 457.95 & 1639.62 & 70.82 & 61.76 & 4617.86 & 357.43 & 5288.18 & 190.66 & 799.82 \\
\hline HREE & 18.89 & 12.20 & 14.45 & 26.07 & 28.21 & 123.38 & 60.10 & 47.43 & 696.80 & 154.55 & 706.10 & 319.66 & 109.33 \\
\hline $\begin{array}{l}\text { LREE/ } \\
\text { HREE }\end{array}$ & 15.33 & 17.20 & 25.11 & 13.77 & 16.23 & 13.29 & 1.18 & 1.30 & 6.63 & 2.31 & 7.49 & 0.60 & 7.32 \\
\hline$(\mathrm{La} / \mathrm{Yb})_{\mathrm{N}}$ & 28.50 & 36.55 & 35.69 & 23.55 & 43.79 & 30.45 & 0.71 & 0.86 & 6.95 & 1.79 & 10.27 & 0.19 & 10.58 \\
\hline$(\mathrm{La} / \mathrm{Sm})_{\mathrm{N}}$ & 4.94 & 5.41 & 8.49 & 4.96 & 4.93 & 4.57 & 1.13 & 1.21 & 3.96 & 1.98 & 3.93 & 0.32 & 2.88 \\
\hline$(\mathrm{Gd} / \mathrm{Yb})_{\mathrm{N}}$ & 3.17 & 3.67 & 2.17 & 2.72 & 4.96 & 3.99 & 0.58 & 0.65 & 1.17 & 0.77 & 1.73 & 0.53 & 2.22 \\
\hline$\delta \mathrm{Eu}$ & 0.29 & 0.39 & 0.30 & 0.20 & 0.19 & 0.09 & 0.47 & 0.40 & 0.05 & 0.22 & 0.03 & 0.14 & 0.09 \\
\hline$\delta \mathrm{Ce}$ & 0.97 & 0.96 & 0.92 & 0.94 & 0.93 & 1.00 & 1.05 & 1.01 & 1.01 & 1.02 & 1.00 & 1.20 & 0.91 \\
\hline
\end{tabular}
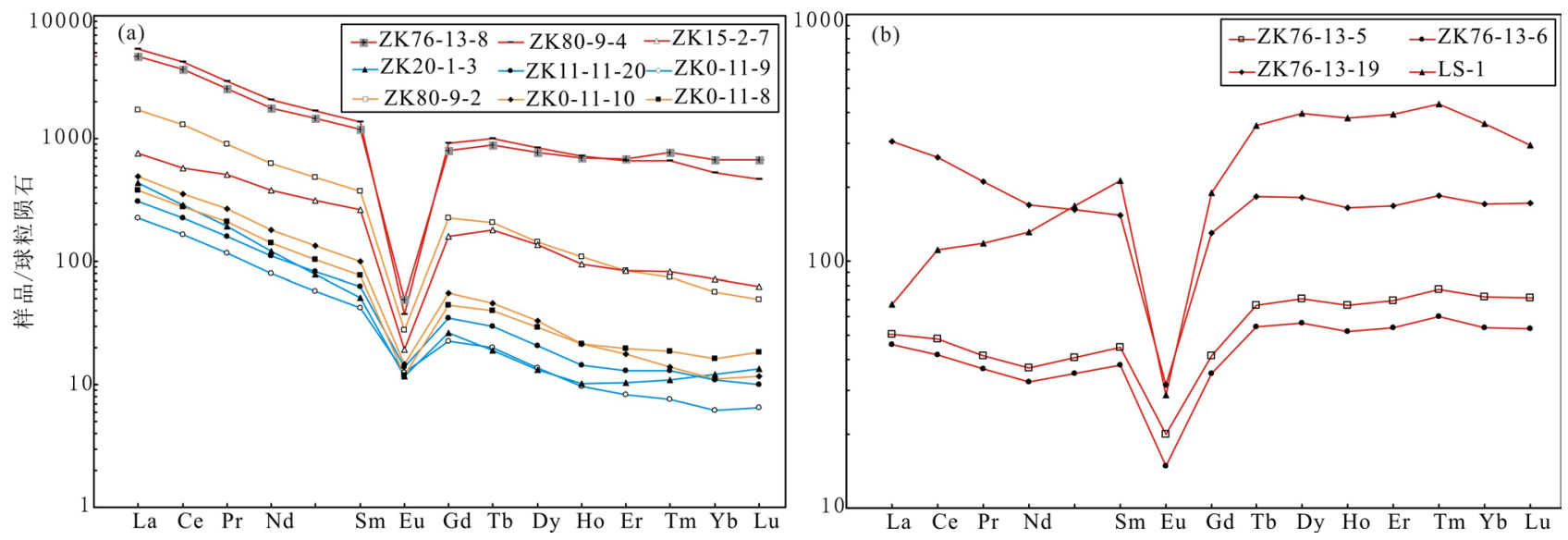

Figure 4. Chondrite-normalized REE distribution patterns of the leucogranites in Gaudeanmus, Namibia (data of chondrite are from [30]). (a) rightinclining type with enrichment of LREE; (b) leftinclining type with enrichment of HREE. 
magmatic crystallization differentiation.

The REE patterns of some uraniferous leucogranites (ZK76-13-5, ZK76-13-6, ZK76-13-19, LS-1) present leftinclining type, LREE/HREE ranged from 0.6 to 2.31, average $1.35,(\mathrm{La} / \mathrm{Yb})_{\mathrm{N}}=0.19-1.79$, average $0.89, \delta \mathrm{Eu}=0.14-0.47$, average $0.31, \delta \mathrm{Ce}=1.01-1.20$, average 1.07 , indicating that these samples are relatively enriched in HREE, without fractionations of REE. $(\mathrm{La} / \mathrm{Sm})_{\mathrm{N}}=0.32-1.98$, average 1.16 , and $(\mathrm{Gd} / \mathrm{Yb})_{\mathrm{N}}=0.53-0.77$, average 0.63 respectively, showing that there is no obvious LREE and HREE internal fractionation. The results suggest uranium mineralization is controlled by later hydrothermal.

\section{Ore Forming Fluid Geochemistry}

A systematic research on the ore-forming fluid, can judge the uranium mineralization stages and different uranium mineralization [31]. Therefore, a detailed study of the quartz inclusion in mineralization granite and quartz veins, found that there are two periods of ore-forming fluid. The primary inclusions of main metallogenic epoch are isolated or clustered, homogenization temperature concentrated in $470^{\circ} \mathrm{C}-530^{\circ} \mathrm{C}$ (Figure 5), salinity is $3.55 \%-9.60 \%$ NaCleq, mean $6.14 \% \mathrm{NaCleq}$. It belongs to magnatic residual high temperature and low salinity fluid. Another inclusions is secondary, distributed as linear or banded, homogenization temperature ranges from $150^{\circ} \mathrm{C}$ to $220^{\circ} \mathrm{C}$ (Figure 5), salinity is $4.65 \%$ $19.05 \%$ NaCleq, average $11.5 \%$ NaCleq. Obviously, the late hydrothermal fluids for reformation is mid-low temperature, low salinity fluid [32].

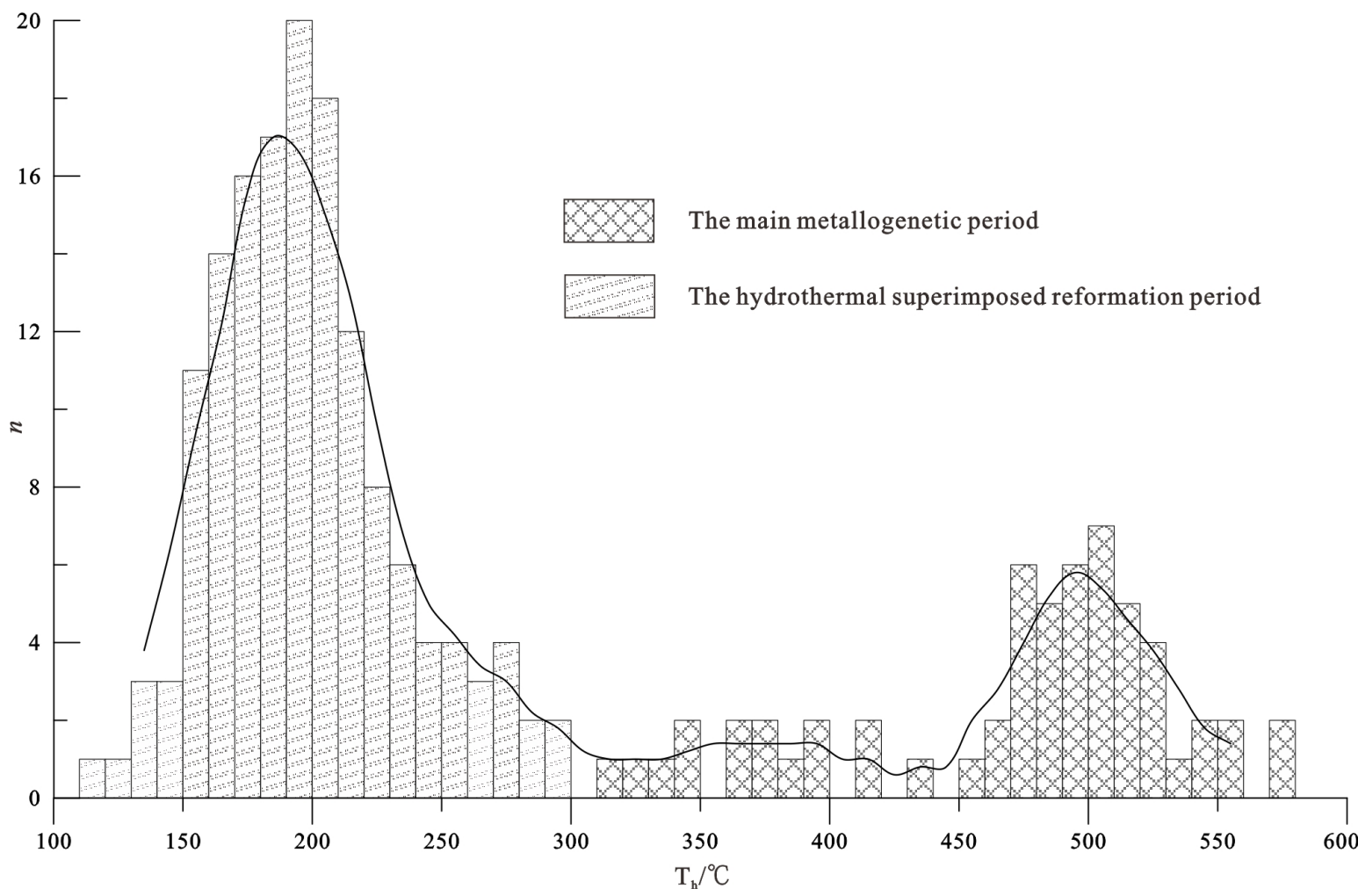

Figure 5. Histogram showing homogenization temperatures of fluid inclusions of leucogranite-type uranium deposit in Gaudeanmus area, Namibia. 


\section{Discussion}

\subsection{Correlation between Trace Elements and Uranium Mineralization}

In order to find out the trace elements which are closely related with $\mathrm{U}$, correlation and R-type clustering analyses have been made to the non-mineralized, weak-mineralized, uraniferous leucogranites by SPSS statistical software (Table 3, Figure 6). The results show the relationship between trace elements and $U$ is not consistent from non-mineralized to uraniferous leucogranites. Therefore, this study focuses on the uraniferous leucogranites to investigate the relationship between trace elements and $\mathrm{U}$.

Table 3. Correlation coefficients of $U$ and trace elements of leucogranites in Gaudeanmus, Namibia.

\begin{tabular}{ccccccccccc}
\hline Element & $\mathrm{Sc}$ & $\mathrm{Cr}$ & $\mathrm{Co}$ & $\mathrm{Ni}$ & $\mathrm{Cu}$ & $\mathrm{Zn}$ & $\mathrm{Rb}$ & $\mathrm{Sr}$ & $\mathrm{Nb}$ & $\mathrm{Mo}$ \\
\hline Non-mineralized leucogranite & 0.984 & 0.906 & -0.424 & -0.792 & -0.923 & 0.957 & 0.879 & -0.884 & 0.955 & 0.336 \\
Weak-mineralized leucogranite & 0.960 & 0.935 & 0.949 & 0.965 & 0.945 & 0.936 & 0.905 & 0.921 & 0.942 & 0.938 \\
Uraniferous leucogranite & 0.685 & 0.339 & 0.793 & 0.855 & 0.260 & 0.318 & -0.391 & 0.246 & 0.754 & 0.385 \\
\hline Element & $\mathrm{Sb}$ & $\mathrm{Cs}$ & $\mathrm{Ba}$ & $\mathrm{Ta}$ & $\mathrm{W}$ & $\mathrm{Pb}$ & $\mathrm{Th}$ & $\mathrm{Zr}$ & $\mathrm{Hf}$ & $\Sigma \mathrm{REE}$ \\
\hline Non-mineralized leucogranite & -0.976 & 0.621 & 0.811 & 0.990 & 0.612 & 1.000 & -0.942 & -0.880 & -0.878 & -0.625 \\
Weak-mineralized leucogranite & 0.956 & 0.917 & 0.863 & 0.900 & 0.958 & 0.936 & 0.874 & 0.678 & 0.685 & 0.902 \\
Uraniferous leucogranite & -0.427 & 0.293 & -0.717 & 0.117 & 0.002 & 0.997 & 0.963 & 0.587 & 0.527 & 0.849 \\
\hline
\end{tabular}

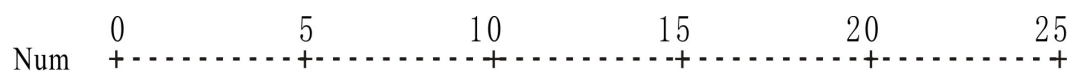

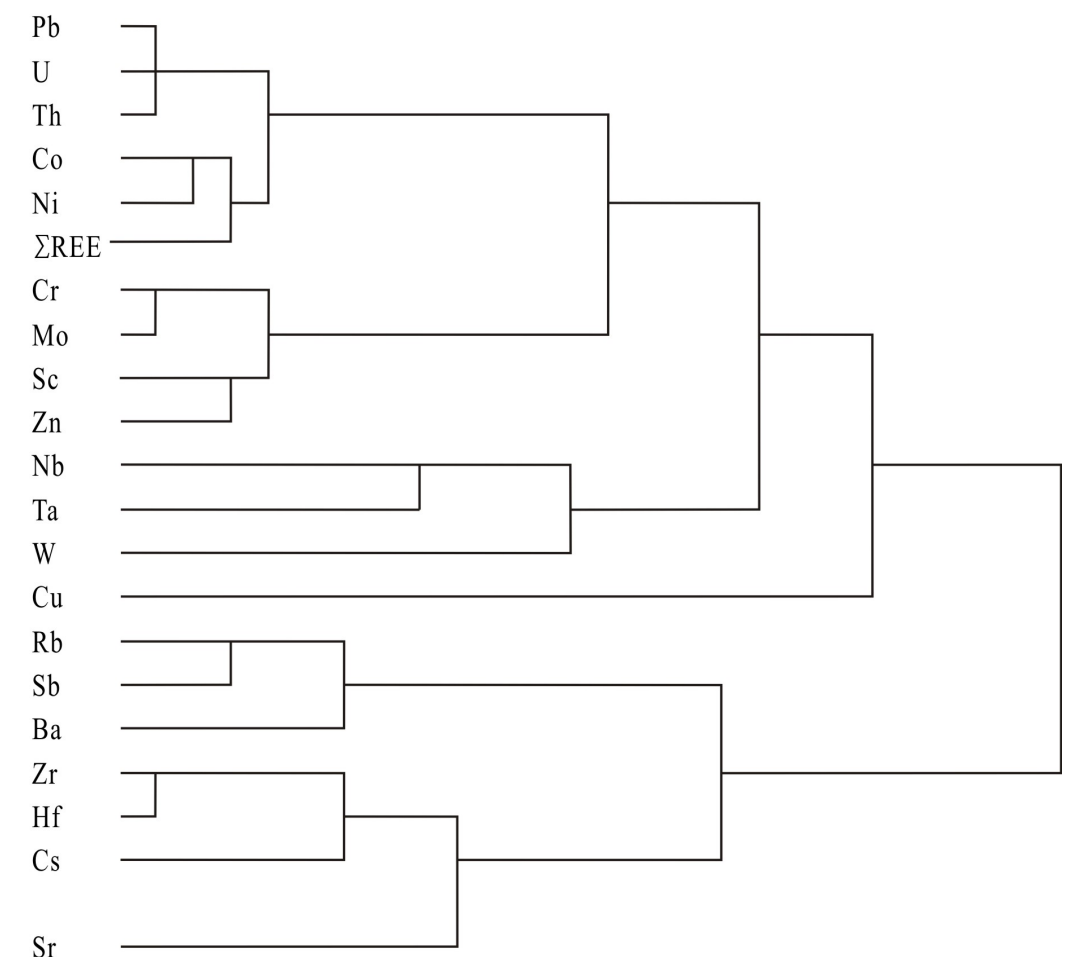

Figure 6. R-type cluster analysis of trace elements of the uraniferous leucogranites in Gaudeanmus, Namibia. 

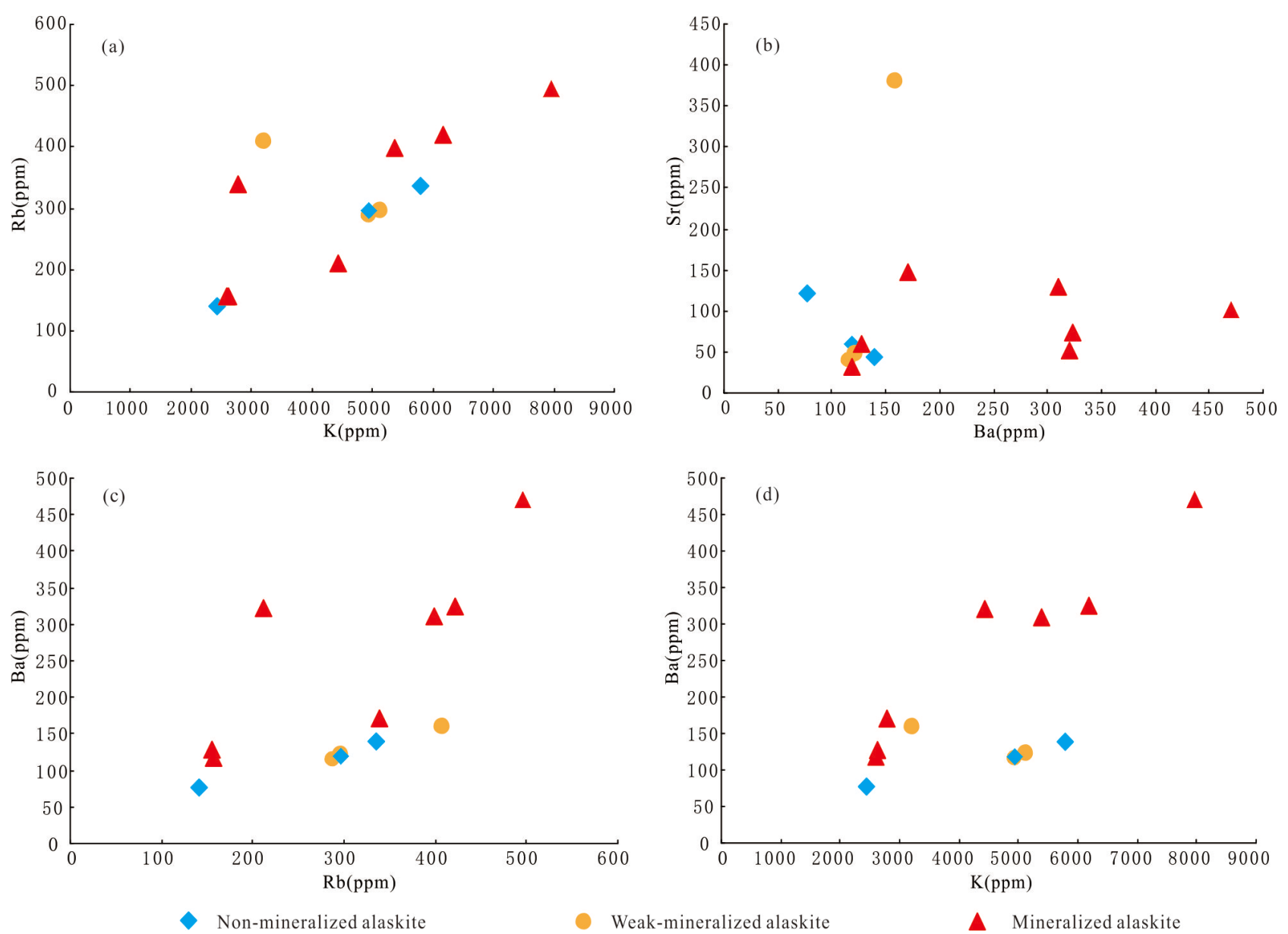

Figure 7. Graphs of LILE variation for the leucogranites in Gaudeanmus, Namibia: (a) K vs Rb; (b) Ba vs Sr; (c) Rb vs Ba; (d) K vs Ba. 
diagram (Figure 7(b)), the mineralised leucogranites have been obviously affected by later hydrothermal reformation. This result is consistent with the phenomenon which mineralised leucogranites occurred kaolinization, sericitization, chloritization, pyritization and hematitization.

Later hydrothermal reformation leads to uranium mineralization again, this opinion also can be confirmed by the leftinclining type REE patterns. It is a common phenomenon that there is an increase in the contents of REE and HREE in the process of hydrothermal uranium mineralization, especially HREE [34] [35] [36]. The principal reasons are as follows: 1) Affected by the "lanthanide contraction", the decrease in ionic radius of HREE and increase in ionization potential, thus relatively enhance the coordination ability of HREE, which makes sense intuitively as the HREE are stronger in mobility with the complexes than LREE, finally causes the fractionation between LREE and HREE of the hydrotherm; 2) REE and $U$ can move together with the analogous complexes in the hydrotherm. A large number of studies have indicated that metallogenic hydrothermal uranium mainly migrate as the form of uranyl carbonate ligands in $\mathrm{UO}_{2}\left(\mathrm{CO}_{3}\right)_{2}^{2-}$ and $\mathrm{UO}_{2}\left(\mathrm{CO}_{3}\right)_{3}^{4-}$ [37] [38] [39], $\mathrm{CO}_{2}$ of metallogenic hydrotherm promotes the mobilization of uranium. Research on the fluid inclusions in uraniferous leucogranites, indicates that there are a great quantity of $\mathrm{CO}_{2}$ in the ore-forming fluid. Therefore, it can be inferred that the hydrothermal uranium in this stage move also in the form of $\mathrm{UO}_{2}\left(\mathrm{CO}_{3}\right)_{2}^{2-}$ and $\mathrm{UO}_{2}\left(\mathrm{CO}_{3}\right)_{3}^{4-}$. In the rich $\mathrm{HCO}_{3}^{-}$hydrotherm, $\mathrm{U}$, Th and HREE have a more similar geochemical behavior, and the ability to form complexes with HREE is far greater than LREE [39]. Then, in the process of hydrothermal uranium mineralization, HREE are much more enriched than LREE. Pitchblende and veined coffinite are the representative uranium minerals of this stage.

\subsection{Origin of Mineralizing Fluid}

Stable isotope is an important method of researching deposits and tracing ore-forming fluid. This study tested 6 quartzs of uraniferous leucogranites and 3 quartz veins, the analysis results are shown in Table 4. $\delta^{18} \mathrm{O}_{\mathrm{Qtz}}$ of Six quartz samples changes from $13.3 \%$ - $14.4 \%$, average $13.65 \%$, according to the fluid inclusion temperature mode and quartz-water system oxygen isotope equilibrium fractionation equation [40], the calculation of $\delta^{18} \mathrm{O}_{\mathrm{H} 2 \mathrm{O}}$ varies from $7.71 \%$ to $8.81 \%$, an average of $8.06 \%$, $\delta 18 \mathrm{D}$ is from $-53.3 \%$ o to $-46.4 \%$, indicating that this period uranium mineralization is magmatic hydrothermalism. $\delta^{18} \mathrm{O}_{\mathrm{Qtz}}$ of Superimposed phase quartz vein samples is between $13.2 \%$ and $13.7 \%$, an average of $13.5 \%$, the calculated $\delta^{18} \mathrm{O}_{\text {Н2О }}$ changes in $1.49 \%$ - $1.99 \%$, mean $1.79 \%$, $\delta^{18} \mathrm{D}$ varies from $-64.7 \%$ to $-53.6 \%$.

In the $\delta \mathrm{D}-\delta^{18} \mathrm{O}_{\mathrm{H} 2 \mathrm{O}}$ diagram (Figure 8), $\mathrm{H}$ and $\mathrm{O}$ isotope values of the main metallogenic stage were distributed in the magmatic water area, reflect that the period uranium mineralization is formed by magmatic crystallization differentiation. Besides, ${ }^{143} \mathrm{Nd} /{ }^{144} \mathrm{Nd},{ }^{87} \mathrm{Sr} /{ }^{86} \mathrm{Sr}$ and $\mathrm{Sm} / \mathrm{Nd}$ ratios of uraniferous leucogranites are consistant with that of Abbabis complex and Etusis strata [41]. Therefore, 
Table 4. $\mathrm{C}, \mathrm{H}$ and $\mathrm{O}$ isotope composition of uraniferous leucogranite quartzs and quartz veins in Gaudeanmus Area, southern Central Zone, Damara Orogen, Namibia.

\begin{tabular}{cccccc}
\hline Sample no. & Lithology & $\delta^{88} \mathrm{O}_{\mathrm{Qtz}}(\%)$ & $\begin{array}{c}\delta^{18} \mathrm{O}_{\mathrm{H} 2 \mathrm{O}} \\
(\% \mathrm{o})\end{array}$ & $\delta \mathrm{D}(\%)$ & $\delta \mathrm{C}_{\mathrm{PDB}}(\%)$ \\
\hline ZK76-13-2 & & 13.3 & 7.71 & -52.3 & -13.6 \\
ZK76-13-8 & & 14.4 & 8.81 & -49.3 & -20.8 \\
ZK76-13-10 & Quartz in the & 13.6 & 8.01 & -50.9 & -23 \\
ZK76-13-12 & uraniferous & 13.8 & 8.21 & -46.4 & -19.2 \\
ZK76-13-16 & & 13.5 & 7.91 & -51 & -19.7 \\
ZK84-6-1 & & 13.3 & 7.71 & -53.3 & -19 \\
ZK76-9-1 & & 13.2 & 1.49 & -64.7 & -14.1 \\
$13 \mathrm{H}-3$ & Quartz vein & 13.6 & 1.89 & -60.1 & -20.3 \\
$13 \mathrm{H}-5$ & & 13.7 & 1.99 & -53.6 & -3.7 \\
\hline
\end{tabular}

Note: the $\delta^{18} \mathrm{O}_{\mathrm{H} 2 \mathrm{O}}$ values of ore fluids were calculated using the quartz-water equilibrium fractionation equation $1000 \ln \alpha_{\mathrm{Qtz}-\mathrm{H} 2 \mathrm{O}}=3.38 \times 10^{6} / \mathrm{T}^{2}-3.40$ [40], the temperatures of uraniferous leucogranite quartzs and quartz veins are $\mathrm{T}_{1}=340^{\circ} \mathrm{C}$ (average homogenization temperature of three-phase inclusions), $\mathrm{T}_{2}=200^{\circ} \mathrm{C}$ (average homogenization temperature of inclusion), respectively [32].

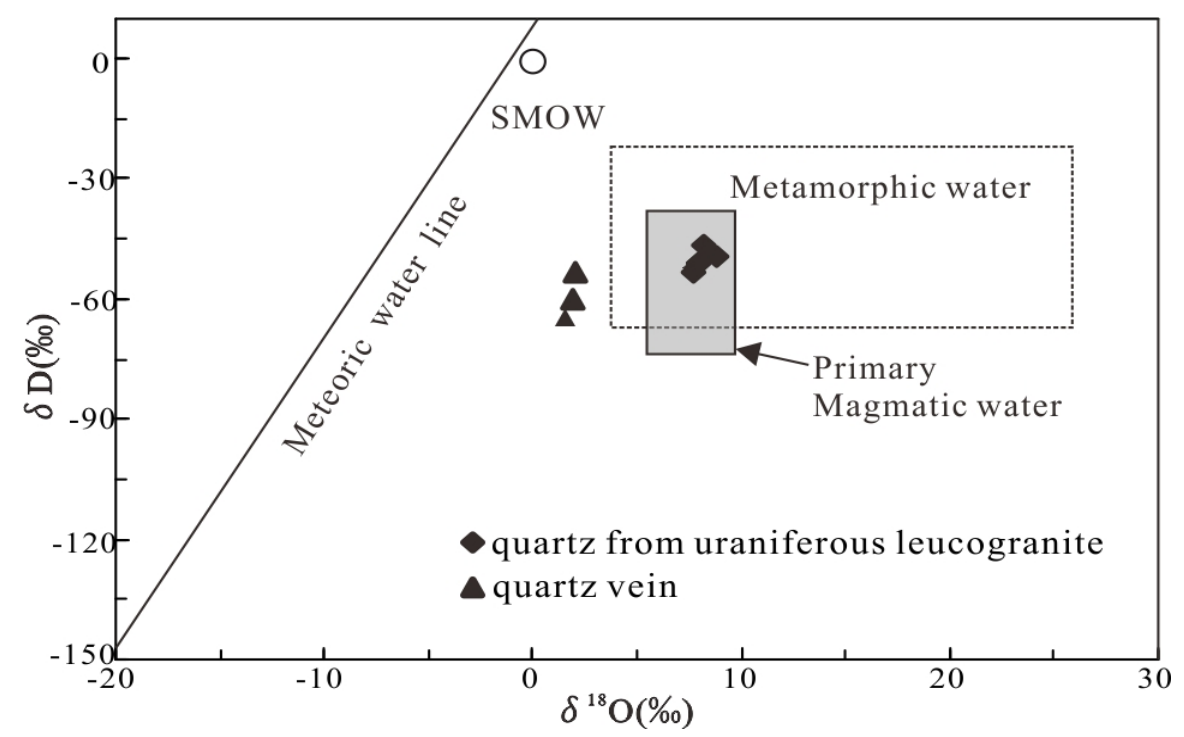

Figure 8. $\delta \mathrm{D}-\delta^{18} \mathrm{O}_{\mathrm{H} 2 \mathrm{O}}$ diagram of mineralizing fluid in Gaudeanmus Area, southern Central Zone, Damara Orogen, Namibia.

uranium mainly source from Abbabis and Etusis. $\mathrm{H}$ and $\mathrm{O}$ isotope values of the superimposed reformation stage deviates significantly from magmatic water area, drifts towards the meteoric water line, indicating that the period mineralizing fluid is post-magmatic hydrothermal fluid mixed with meteoric water.

In addition, the $\delta^{13} \mathrm{C}_{\mathrm{PDB}}$ of quartz veins ranges from $-20.3 \%$ to $-3.7 \%$, average $-12.7 \%$, is close to $\sigma^{13} \mathrm{C}$ value of $\mathrm{CO}_{2}$ in atmosphere or freshwater $(-11 \%$ $-7 \%$ ) [42], and may be mixed with organic carbon, revealing that $\sigma^{13} \mathrm{C}$ of late quartz veins is derived mostly from atmosphere or freshwater. The $\delta^{13} \mathrm{C}_{\mathrm{PDB}}$ of quartz in the uraniferous leucogranites is between $-23 \%$ and $-13.6 \%$, mean $-19.22 \%$, basically within the $\sigma^{13} \mathrm{C}$ range of magmatic lineage $(-30 \%$ - $-3 \%$ ) 
[42], therefore, $\sigma^{13} \mathrm{C}$ of the uraniferous leucogranites stems chiefly from the magma. In conclusion, leucogranite uranium mineralization is chiefly formed by magmatic crystallization differentiation, with late hydrothermal reformation.

\section{Conclusions}

1) The contents of total rare earth elements in the non-mineralized, weak-mineralized, uraniferous leucogranites are 222.02 - $377.26 \mathrm{ppm}$ (mean 302.59 ppm), 385.06 - 1763.00 ppm (mean 878.07 ppm), 109.19 - 5994.28 ppm (mean $1925.79 \mathrm{ppm}$ ), respectively, showing that there is an obvious growth trend from non-mineralized to uraniferous leucogranites, it suggests that uranium mineralization presents synchronous increase trend with REE. $\delta \mathrm{Eu}=0.03-0.47$, with an average of 0.22 , indicating that magma experienced strong differentiation crystallization.

2) In Gaudeanmus, leucogranites show enrichment in large ion lithophile elements, especially $\mathrm{Rb}, \mathrm{Th}, \mathrm{U}, \mathrm{Pb}$, and relative depletion in $\mathrm{Ti}, \mathrm{P}, \mathrm{Sr}$ and $\mathrm{Ba}$. In the uraniferous leucogranites, there is a high correlation between $\mathrm{U}$ and $\mathrm{Pb}, \mathrm{Th}$, $\mathrm{Co}, \mathrm{Ni}$, REE, the correlation coefficient is $0.793-0.997$, indicating that $\mathrm{U}$ is highly homologous with $\mathrm{Pb}$, Th and REE.

3) The leucogranite-type uranium deposite in Gaudeanmus can be divided into two stages: one is main metallogenic epoch, the representative uranium minerals of this stage formed by magmatic crystallization differentiation, which are uraninite, thor-uraninite, coffinite, uranothorite, brannerite and betafite. And the REE pattern is characterized by rightinclining type with obvious Eu negative abnormity and enrichment of LREE. The other is secundarii metallogenic epoch, secondary uranium minerals of this stage produced by later hydrothermal reformation, representing by pitchblende and veined coffinite. And this REE pattern manifests as leftinclining type with obvious Eu negative abnormity and enrichment of HREE.

4) The main mineralization temperature of uraniferous leucogranites concentrates on $470^{\circ} \mathrm{C}-530^{\circ} \mathrm{C}$, the salinity is $3.55 \%-9.60 \% \mathrm{NaCleq}$, with $\mathrm{C}, \mathrm{H}$ and $\mathrm{O}$ isotopic characteristics of typical magmatic source, $-23 \%$ - $-13.6 \%$, $-53.3 \%$ $-46.4 \%$, $7.71 \%$ - $8.81 \%$, respectively, further revealing that the leucogranite-type uranium deposit in Gaudeanmus area was chiefly formed by magmatic crystallization differentiation. The temperature of superposed hydrothermal fluid centeres on $150^{\circ} \mathrm{C}-220^{\circ} \mathrm{C}$, the salinity is $4.65 \%-19.05 \% \mathrm{NaCleq}, \mathrm{C}, \mathrm{H}$ and $\mathrm{O}$ isotope is $-20.3 \%$ - $-3.7 \%$ o, $-64.7 \%$ - $-53.6 \%$, $1.49 \%$ - $1.99 \%$, reflects this period hydrothermal reformation mixed with atmospheric water.

\section{References}

[1] Berning, J., Cooke, R., Hiemstra, S.A. and Hoffman, U. (1976) The Rössing Uranium Deposit, South West Africa. Economic Geology, 71, 351-368. https://doi.org/10.2113/gsecongeo.71.1.351

[2] Marlow, A.G. (1981) Remobilisation and Primary Uranium Genesis in the Damaran Orogenic Belt, Namibia. Unpublished Ph.D. Thesis, University of Leeds.

[3] Mouillac, J.L., Valois, J.P. and Walgenwitz, F. (1986) The Goanikontes Uranium 
Occurrence in South West Africa/Namibia. In: Anhaeusser, C.R. and Maske, S. Eds., Mineral Deposits of Southern Africa. Volume II, Geological Society of South Africa, Johannesburg, 1833-1843.

[4] Nex, P.A.M. and Kinnaird, J.A. (1995) Granites and Their Mineralisation in the Swakop River Area around Goanikontes, Namibia. Communications of the Geological Survey of Namibia, 10, 51-56.

[5] Nex, P.A.M. (1997) Tectono-Metamorphic Setting and Evolution of Granitic Sheets in the Goanikontes Area, Namibia. Unpublished Ph.D. Thesis, National University of Ireland, $322 \mathrm{p}$.

[6] Söhnge, G. (2001) Journal of a Geologist. Geology Department, Stellenbosch University, $197 \mathrm{p}$.

[7] Kinnaird, J.A. and Nex, P.A.M. (2007) A Review of Geological Controls on Uranium Mineralisation in Sheeted Leucogranites within the Damara Orogen, Namibia. Applied Earth Science (Trans. Inst. Min. Metall. B), 116, 68-85.

[8] Greenaway, G. (2007) Valencia Uranium Pty Ltd: Valencia Project, Namibia-Resource Update. Technical Report, Snowden Group.

[9] Guy, G.F. (2010) Petrographic, Mineralogical and Geochemical Characterisation of Granite-Hosted Uranium Deposits of the Central Damara Orogen, Namibia. Unpublished Ph.D. Thesis. University of the Witwatersrand Johannesburg.

[10] Chen, J.Y., Fan, H.H., Chen, D.H., Gu, D.Z. and Wang, S.Y. (2013) Research on the Characteristics of Uranium Minerals of Alaskite-type Uranium Deposit in the Gaudeanmus Area, Namibia. Geological Review, 59, 962-970.

[11] Chen, J.Y., Fan, H.H., Chen, D.H., Gu, D.Z. and Wang, S.Y. (2014) Texture and Structure of Ore and Genesis of Alaskite-Type Uranium Deposit in the Gaudeanmus Area, Namibia. Bulletin of Mineralogy, Petrology and Geochemistry, 33, 91-97.

[12] Briqueu, L., Lancelot, J.R., Valois, J.P. and Walgenwitz, F. (1980) Géochronologie $\mathrm{U}-\mathrm{Pb}$ et genèse d'un type de minéralisation uranifère: Les alaskites de Goanikontès (Namibie) et leur encaissant. Bull. Centre Rech. Explor. Prod. Elf. Aquitaine, 4, 759-811.

[13] Nex, P.A.M., Kinnaird, J.A. and Oliver, G.J.H. (2001) Petrology, Geochemistry and Uranium Mineralisation of Post Collisional Magmatism around Goanikontes, Southern Central Zone, Namibia. Journal of African Earth Sciences, 33, 481-502. https://doi.org/10.1016/S0899-5362(01)00096-3

[14] Herd, D.A. (1996) Geochemistry and Mineralisation of Alaskite in Selected Areas of the Rössing Uranium Mine, Namibia. M.Sc. Dissertation (Unpubl.), University of St. Andrews, Scotland, 1-144.

[15] Zhang, Z.S., Hua, R.M., Liu, X.D., Deng, P. and Wu, L.Q. (2005) Geochemical Characteristics of Rare Earth Elements of Guidong Granitic Compiex and Their Relationship with Uranium Mineralization. Journal of the Chinese Rare Earth Society, 23, 749-756.

[16] Mercadier, J., Cuney, M., Lach, P., Boiron, M.-C., Bonhoure, J., Richard, A., Leisen, M. and Kister, P. (2011) Origin of Uranium Deposits Revealed by Their Rare Earth Element Signature. Terra Nova, 23, 264-269. https://doi.org/10.1111/j.1365-3121.2011.01008.x

[17] Qi, J.M., Xu, Z.Q., Liang, J., Tang, C.Y., Ni, S.J., Zhang, C.J. and Cheng, F.G. (2013) Geochemical Characteristics of Trace Elements and Its Significance in Uranium Deposit 376, North Guangxi. Uranium Geology, 29, 1-8.

[18] Coward, M.P. (1983) The Tectonic History of the Damara Belt. In: Miller, R., Ed., Special Publication of the Geological Society of South Africa, 11, 409. 
[19] Martin, H. and Porada, H. (1977) The Intracratonic Branch of the Damaran Orogen in Namibia. Discussion of Geodynamic Models. Precambrian Research, 5, 311-338. https://doi.org/10.1016/0301-9268(77)90039-0

[20] Shawn, K. (2008) Structural Controls of Auriferous Quartz Veins in the Karibib Area, Southern Central Zone of the Pan-African Damara Belt, Namibia. Master's Thesis of Stellenbosch University.

[21] Corner, B. (1983) An Interpretation of the Aeromagnetic Data Covering the Western Portion of the Damara Orogen in South West Africa/Namibia. Special Publication of the Geological Society of South Africa, 11, 339-354.

[22] Roesener, H. and Schreuder, C.P. (1994) "Nuclear and Fossil Fuels-Uranium" in Mineral Resources of Namibia. 1-59.

[23] Miller, R. (1983) The Okahandja Lineament, a Fundamental Tectonic Boundary in the Damara Orogen of South West Africa/Namibia. Transactions of the Geological Society of South Africa, 349-510.

[24] Kröner, A., Retief, E.A., Compston, W., Jacob, R.E. and Burger, A.J. (1991) Single Grain and Conventional Zircon Dating of Remobilised Basement Gneisses in the Central Damara Belt of Namibia. South African Journal of Geology, 94, 379-387.

[25] Hoffman, K.H., Hawkins, D.P., Isachsen, C.E. and Bowring, S.A. (1996) Precise U-Pb Zircon Ages for Early Damaran Magmatism in the Summas Mountains and Welwischia Inlier, Northern Damara Belt, Namibia. Communications-Geological Surcey of Namibia, 11, 47-52.

[26] Hoffman, K.H., Condon, D.J., Bowring, S.A. and Crowley, J.L. (2004) U-Pb Zircon Date from the Neoproterozoic Ghaub Formation, Namibia: Constraints on Marinoan Glaciation. Geology, 32, 817-820. https://doi.org/10.1130/G20519.1

[27] Qu, X.M., Hou, Z.Q. and Li, Y.G. (2004) Melt Components Derived from a Subducted Slab in Late Orogenic Ore-Bearing Porphyries in the Gangdese Copper Belt, Southern Tibetan Plateau. Lithos, 74, 131-148. https://doi.org/10.1016/j.lithos.2004.01.003

[28] Boynton, W.V. (1984) Geochemistry of the Rare Earth Elements: Meteorite Studies. In: Henderson, P., Ed., Rare Earth Elements Geochemistry, Elservier, Amstrdam, 63-114. https://doi.org/10.1016/B978-0-444-42148-7.50008-3

[29] Gao, S., Luo, T.C., Zhang, B.R., Zhang, H.F., Han, Y.W., Zhao, Z.D. and Kern, H. (1999) Structure and Composition of the Continental Crust in East China. Science in China (Series D), 29, 204-213.

[30] Sun, S.S. and McDonough, W.F. (1989) Chemical and Isotopic Systematics of Oceanic Basalts: Implications for Mantle Composition and Processes. In: Saunders, A.D., Norry, M.J., Eds., Magmatism in the Ocean Basins, Geological Society, London, Special Publications, 42, 313-345. https://doi.org/10.1144/GSL.SP.1989.042.01.19

[31] Nex, P.A.M., Herd, D. and Kinnaird, J.A. (2002) Fluid Extraction from Quartz in Sheeted Leucogranites as a Monitor to Styles of Uranium Mineralisation: An Example from the Rössing Area, Namibia. Geochemistry: Exploration, Environment, Analysis, 2, 83-96. https://doi.org/10.1144/1467-787302-009

[32] Fan, H.H., Chen, J.Y., Gu, D.Z. and Wang, S.Y. (2015) The Fluid Inclusions and Metallogenesis of Alaskite-Type Uranium Deposit in the Gaudeanmus Area, Namibia. Mineral Deposits, 34, 189-199.

[33] Plant, J.A., Simpson, P.R., Smith, B. and Windley, B.F. (1999) Uranium Ore Deposits-Products of the Radioactive Earth. In: Burns, P.C. and Finch, R., Eds., Uranium: Mineralogy, Geochemistry and the Environment. Reviews in Mineralogy, Vol. 38, Mineralogical Society of America, 255-319. 
[34] Li, Z.Y. (1987) Rare Earth Element Geochemistry of Granite-Type Hydrothermal Uranium Deposits with Alkaline Metasomatism in Northwest China. Uranium Geology, 8, 175-183.

[35] Chen, D.Y. (1993) Some Geochemical Behaviour of REE and Their Indicating Significance for Hydrothermal Uranium Mineralization. Uranium Geology, 9, 353-357.

[36] Chen, C. (1999) Geochemistry of Rare Earth Elements (REE) in Hydrothermal Uranium Mineralizing Process. Uranium Geology of South China, 16, 20-27.

[37] Cuney, M. (1978) Geologic Environment, Mineralogy, and Fluid Inclusions of the Bois Noirs-Limouzat Uranium Vein, Forez, France. Economic Geology, 73, 15671610.

[38] Chen, Z.B., Xie, Y.X., Wan, G.L., Ji, S.F., Wang, C.L. and Fang, X.H. (1982) Uranium Deposits in Mesozoic Volcanics in South-East China. Acta Geologica Sinica, 56, 235-242.

[39] Hu, R.Z. and Jin, J.F. (1990) Mechanism of the Migration and Deposition of Uranium in Ascending Hydrothermal Solutions-Evidence from the Xiwang Uranium Deposit. Geological Review, 36, 317-325.

[40] Clayton, R.N., O’Neil, J.L. and Mayeda, T.K. (1972) Oxygen Isotope Exchange between Quartz and Water. J. Geophys. Res., 77, 3057-3067. https://doi.org/10.1029/JB077i017p03057

[41] McDermott, F., Harris, N.B.W. and Hawkesworth, C.J. (1996) Geochemical Constraints on Crustal Anatexis: A Case Study from the Pan-African Damara Granitoids of Namibia. Contributions to Mineralogy and Petrology, 123, 406-423. https://doi.org/10.1007/s004100050165

[42] Hoefs, J. (1997) Stable Isotope Geochemistry. 3rd Edition. Springer-Verlag, Berlin. https://doi.org/10.1007/978-3-662-03377-7

Scientific Research Publishing

\section{Submit or recommend next manuscript to SCIRP and we will provide best service for you:}

Accepting pre-submission inquiries through Email, Facebook, LinkedIn, Twitter, etc. A wide selection of journals (inclusive of 9 subjects, more than 200 journals)

Providing 24-hour high-quality service

User-friendly online submission system

Fair and swift peer-review system

Efficient typesetting and proofreading procedure

Display of the result of downloads and visits, as well as the number of cited articles

Maximum dissemination of your research work

Submit your manuscript at: http://papersubmission.scirp.org/

Or contact gep@scirp.org 